\title{
Mortality and cancer morbidity in cohorts of asbestos cement workers and referents
}

\author{
M Albin, K Jakobsson, R Attewell, L Johansson, $\mathrm{H}$ Welinder
}

\begin{abstract}
Total and cause specific mortality and cancer morbidity were studied among 1929 asbestos cement workers with an estimated median cumulative exposure of 2.3 fibre (f)-years/ml (median intensity $1.2 \mathrm{f} / \mathrm{ml}$, predominantly chrysotile). A local reference cohort of 1233 industrial workers and non-case referents from the exposed cohort were used for comparisons. The risk for pleural mesothelioma was significantly increased (13 cases out of 592 deaths in workers with at least 20 years latency). No case of peritoneal mesothelioma was found. A significant dose response relation was found for cumulative exposure 40 years or more before the diagnosis, with a multiplicative relative risk (RR) of 1.9 for each $\mathrm{f}$-year $/ \mathrm{ml}$. No relation was found with duration of exposure when latency was accounted for. There was a significant overrisk in non-malignant respiratory disease $(R R=2 \cdot 6)$. The overall risks for respiratory cancer, excluding mesothelioma, and for gastrointestinal cancer were not significantly increased. Surprisingly, colorectal cancer displayed a clear relation with cumulative dose, with an estimated increase of $1.6 \%$ in the incidence density ratio for each $\mathrm{f}-\mathrm{year} / \mathrm{ml}$ (but not with duration of exposure).
\end{abstract}

Information on dose response relations for asbestos related disease is limited, especially for exposure to low doses and in relation to gastrointestinal cancer. Several studies have implied important differences at the same intensity of exposure between different industrial branches. ${ }^{1}$ Even within the asbestos cement industry, appreciable differences in the

University Hospital, S-221 85 Lund, Sweden

Department of Occupational and Environmental Medicine

M Albin, $\mathrm{K}$ Jakobsson, $\mathrm{R}$ Attewell, $\mathrm{H}$ Welinder

Department of Pathology

L Johansson slopes of dose response curves have been found in different plants. ${ }^{2}$ The reason for this is still not clear, but it is of considerable interest as the asbestos cement industry uses about $70 \%$ of the world asbestos production. ${ }^{3}$

For studies on low dose exposure, presumably dealing with small increases of risk, validity of the comparison between exposure and non-exposure is vital. Therefore, the national general population is probably not an adequate comparison group. Moreover, death rates for such a comparison are usually available only for the last decades, and thereby important information about the experience over time may be lost.

This study presents total and cause specific mortality stratified by age, calendar time, cumulative dose, and duration of employment during the period 1927-86 for cohorts of asbestos cement workers compared with industrial workers not exposed to asbestos cement. We also report results from a nested case referent study of mesothelioma cases, matched for confounding factors, using multivariate methods for the modelling of exposure and latency.

\section{Material and methods \\ THE PLANT}

The plant, situated in the south of Sweden, operated during 1907-78 producing sheets, shingles, ventilation pipes, and various hand moulded details. The asbestos handled was mainly chrysotile ( $>95 \%$ ) and smaller amounts of crocidolite and amosite. Crocidolite was used before 1966 but only for sheets. The amounts used from 1953 were less than $1 \%$ and never exceeded $3-4 \%$ of the total use of asbestos. Amosite (maximum $<18 \%$ total use) was used for a few years during the 1950 s.

Fibre length classes were of the commercial grades 3-7. All types of asbestos were milled before mixing. Only small principal changes in formula or machinery occurred over the history of the plant. One was changing from dry to wet milling in 1952, which made it possible to use shorter fibres. There was also an increasing automation of the process and additions of machinery for processing the products. Systematic efforts to reduce dust concentrations started in the second half of the 1960 s. 
Dust measurements are available for the period 1956-77. The membrane filter method was used from 1969. Before that, only impinger or gravimetric determinations exist. The average dust exposures $(\mathrm{f} / \mathrm{ml})$ for different jobs and periods have been estimated from data on dust concentrations, production, and dust control as averages over five calendar years. Owing to insufficient information, the estimates for 1947-51 have been used for the whole period before 1942 when the production process, as far as we know, was mainly the same. We are aware of many tasks leading to high exposures in the early period, but are not sure to what extent these may affect the exposure for the group as a whole. A general reduction in the dust concentrations was assumed for the period $1942-5$ as the shortage of asbestos caused a reduction in its use.

Only millers, mixers, sawyers, and grinders (15$20^{\circ}$ o of the blue collar workforce) were continuously exposed to greater than $2 \mathrm{f} / \mathrm{ml}$ of dust (table 1 ). Occasional exposure to high dust concentrations occurred during unloading and storing of asbestos bags and performance of certain jobs before the second world war. These tasks could not be related to individual workers and were therefore not accounted for. The Portland cement used had a low silica content $(<0.1 \%$ crystalline silica in the respirable fractions).

The workforce reached a maximum in the mid 1960 s with 450 employees. The turnover of staff was low as the factory was located in a small community.

\section{EXPOSED COHORT}

All male employees registered in the company personnel records for 1907-77 and employed for at least three months were included in the cohort (2898 persons). Vital status was determined until 31 December 1986. The immigrant workers were lost to follow up to a much higher degree than the Swedish subjects $\left(19 v 1^{\circ} \%\right)$, and formed a larger part of the exposed than the reference cohort ( $33 v 11 \%$ ). They were, therefore, excluded from the cohort analysis.

Death certificates were obtained and recoded according to the International Classification of Diseases-8 (ICD-8) by the National Swedish Central Bureau of Statistics, which is responsible for the coding of all Swedish death certificates. The cohort was matched with the regional (1958-86) and national (1958-84) cancer registries. Individual dose estimates could be calculated for 1503 of the 1929 Swedish workers. The median exposure intensity was $1 \cdot 2 \mathrm{f} / \mathrm{ml}$. All available histopathological material was reviewed for respiratory and gastrointestinal cancers, and additional information was collected from necropsy protocols. The reviewer was unaware of the exposure status.

Formalin fixed and paraffin embedded blocks were used for light microscopical and immunohistochemical studies of the 13 pleural tumours. For light microscopical studies, the slides were stained with haematoxylin eosin, and in some cases also Van Gieson, PAS + / - diastase and Alcian Blue (pH 2.5) $+/-$ hyaluronidase. Two coincident tumours in two patients were also examined. The mesotheliomas were classified according to the 1982 World Health Organisation classification of lung carcinomas. ${ }^{4}$

In 12 cases sufficient material for immunohistochemical examination was available. The following antibodies were used: epithelial membrane antigen (EMA), vimentin, carcinoembryonic antigen (CEA), desmin (DAKO, Copenhagen, Denmark), cytokeratin AE1/AE3 (Hybritechs, San Diego, California), and CAM 5.2 (Becton \& Dickinson, Lonbard, Illinois). The staining was scored 0 to 2 (absent, weak, or strong).

\section{REFERENT COHORT}

A reference cohort was formed by combining subcohorts (a total of 1552 persons) from five different industries in the region (fertiliser production,

Table 1 Average measured and estimated concentrations of total dust, particles, and fibres in air during different work processes

\begin{tabular}{|c|c|c|c|c|c|c|c|c|c|}
\hline \multirow[b]{2}{*}{$\begin{array}{l}\text { Job } \\
\text { assignment }\end{array}$} & \multicolumn{3}{|l|}{1956} & \multirow{2}{*}{$\frac{1965}{\begin{array}{l}\text { Particlest } \\
\text { (mppcf) }\end{array}}$} & \multicolumn{3}{|l|}{1969} & \multicolumn{2}{|l|}{1975} \\
\hline & $\begin{array}{l}\text { Particlest } \\
\text { (mppcf) }\end{array}$ & $\begin{array}{l}\text { Total dust } \ddagger \\
\left(\mathrm{mg} / \mathrm{m}^{3}\right)\end{array}$ & $\begin{array}{l}\text { Fibres\} } \\
(f / m l)\end{array}$ & & $\begin{array}{l}\text { Particlest } \\
\text { (mppcf) }\end{array}$ & $\begin{array}{l}\text { Fibres } \| \\
(f \mid m l)\end{array}$ & $\begin{array}{l}\text { Total dust } \ddagger \\
\left(\mathrm{mg} / \mathrm{m}^{3}\right)\end{array}$ & $\begin{array}{l}\text { Total dust } \ddagger \\
\left(m g / m^{3}\right)\end{array}$ & $\begin{array}{l}\text { Fibres } \| \\
(f \mid m l)\end{array}$ \\
\hline $\begin{array}{l}\text { Milling } \\
\text { Mixing } \\
\text { Machine line } \\
\text { Sawing } \\
\text { Grinding }\end{array}$ & $\begin{array}{r}15 \\
29 \\
8 \\
24 \\
47\end{array}$ & $\begin{array}{l}6 \cdot 7 \\
5 \cdot 5 \\
2 \cdot 8 \\
0 \cdot 7\end{array}$ & $\begin{array}{l}6 \cdot 0 \\
3 \cdot 0 \\
1 \cdot 5 \\
4 \cdot 0 \\
6 \cdot 3\end{array}$ & $\begin{array}{r}21 \\
4 \\
11 \\
16 \\
45\end{array}$ & $\begin{array}{r}11 \\
3 \\
2 \\
9 \\
9\end{array}$ & $\begin{array}{l}5 \cdot 0 \\
0 \cdot 3 \\
0 \cdot 3 \\
1 \cdot 7 \\
-\end{array}$ & $\begin{array}{l}3 \cdot 3 \\
0 \cdot 5 \\
2 \cdot 5 \\
-\end{array}$ & $\begin{array}{l}4 \cdot 5 \\
5 \cdot 0 \\
2 \cdot 3 \\
4 \cdot 5 \\
4 \cdot 0\end{array}$ & $\begin{array}{l}1 \cdot 7 \\
1 \cdot 3 \\
0 \cdot 9 \\
1 \cdot 2 \\
1 \cdot 5\end{array}$ \\
\hline
\end{tabular}

$\star$ Personal sampling, except total dust in 1956.

†Impinger method.

† Gravimetric method.

Estimated time weighted averages from data on dust concentrations, production, and dust control used for the dose calculations.

IMembrane filter method.

mppcf $=$ Million particles per cubic foot. 
slaughter house, wool and polyester textile, sugar refinery, and metal industries) that were not known to have processed asbestos. Workers who nevertheless held jobs with suspected exposure to asbestos (electricians, carpenters, repairmen, bricklayers, and firemen; a total of 142 persons) were excluded from the analysis. The subjects finally included (1233 Swedish men) fulfilled the same requirements as the asbestos cement workers. Vital status was established, death certificates were coded, and tumours were searched for in the cancer registries in the same way as for the exposed cohort. Loss to follow up was $0 \cdot 2^{\circ}{ }_{0}$.

\section{STATISTICAL ANALYSIS}

A direct comparison of the incidence density (deaths per person-years) between the cohorts over calendar time (1927-86) and age grouped in 10 year intervals, was performed by Poisson regression modelling. ${ }^{56}$ The relative risk ( $R R$; incidence density ratio, exposed $v$ referent) and the $95 \%$ confidence interval (CI) were then estimated with simultaneous adjustment for possible confounding by age and calendar year. The cancer morbidity (1958-86) was analysed in a similar way (but with five year intervals). A minimum latency of 20 years since start of employment (in both cohorts) was used in the analysis. The data for the exposed cohort were further subdivided according to the years worked (and also total cumulative dose up to end of employment) in order to test for dose response relations. The mean employment time was used as a covariate. For cumulative dose the median was used, as the distribution was skew even within each exposure category.
The dose response relations for pleural mesothelioma were also evaluated with a case-referent study nested within the cohort. In this analysis, both Swedish (one case excluded due to missing exposure information) and immigrant workers (two additional cases) were included. For each of the 14 cases, up to five of the closest controls (11 complete sets) of the same nationality, alive at the time of the diagnosis of $\propto$ the case, and within four years of year of birth and \& first employment were chosen. Within each matched set, time was divided into the periods $0-9,10-19,20$ $29,30-39$, and 40 years or more before the diagnosis of the case. Within each period, the total cumulative exposure, as well as average intensity and years employed, were calculated. Conditional logistic regression ${ }^{7}$ was performed using multiplicative models of $R R$ with cumulative exposure or duration or intensity of exposure or both, in each period as continuous variables. Each latency period made a separate contribution in order to identify the most important period with respect to the diagnosis.

\section{Results}

OVERALL COMPARISON BETWEEN COHORTS

When compared with the reference cohort, the $\vec{\theta}$ exposed group had a significantly increased overa and cause specific mortality from malignant and other respiratory disease and from all malignancie The overall risks for heart disease (coronary and unspecified) and for gastrointestinal cancer were not increased (table 2).

The difference in respiratory cancer mortality between the two cohorts was mainly due to a high number of pleural mesotheliomas (13 of a total of 592

Table 2 Overall and cause specific mortality 1927-86 in cohorts of asbestos cement workers and referents (minimum latency time since start of employment 20 years for both cohorts)

\begin{tabular}{|c|c|c|c|c|}
\hline & \multicolumn{2}{|l|}{ Cohort } & & \\
\hline & \multirow{2}{*}{$\begin{array}{l}\text { Asbestos cement } \\
(21978 \text { person-years }) \\
(n=1465)\end{array}$} & \multirow{2}{*}{$\begin{array}{l}\text { Referent } \\
(10910 \text { person-years }) \\
(n=762)\end{array}$} & \multicolumn{2}{|l|}{ Relative risk } \\
\hline & & & Point estimate & $(95 \% C I)$ \\
\hline All causes & 592 & 279 & $1 \cdot 2$ & $(1 \cdot 01-1 \cdot 4)$ \\
\hline Heart disease $^{\star}$ & 219 & 112 & $1 \cdot 1$ & $(0 \cdot 86-1 \cdot 4)$ \\
\hline Non-malignant respiratory disease & 56 & 13 & $2 \cdot 6$ & $(1.4-4.9)$ \\
\hline All malignancies & 164 & 58 & $1 \cdot 6$ & $(1 \cdot 2-2 \cdot 1)$ \\
\hline Respiratory cancer: & 47 & 10 & 2.5 & $(1 \cdot 3-5 \cdot 0)$ \\
\hline Except mesothelioma & 35 & 10 & $1 \cdot 8$ & $(0 \cdot 90-3 \cdot 7)$ \\
\hline Mesotheliomat & 13 & 1 & $7 \cdot 2$ & $(0.97-54)$ \\
\hline Gastrointestinal cancer + : & 49 & 22 & $1 \cdot 2$ & $(0 \cdot 7-2 \cdot 0)$ \\
\hline Upper\$ & 23 & 12 & $1 \cdot 0$ & $(0 \cdot 5-2 \cdot 0)$ \\
\hline Lower\| & 26 & 10 & $1 \cdot 5$ & $(0.7-3 \cdot 0)$ \\
\hline External causes & 37 & 20 & 0.9 & $(0.5-1.6)$ \\
\hline
\end{tabular}

*Ischaemic and unspecified (ICD-8: 410-429).

+ Diagnosis based on histopathological review; one of the exposed and one of the referent cases were originally coded as non-malignant and were therefore not included in the sum of all respiratory cancers (based on death certificates).

IICD-8: 150-154.

\$Oesophagus, stomach, duodenum.

Colon and rectum. 
Table 3 Histopathological and immunohistochemical findings in 14 malignant mesotheliomas in Swedish asbestos cement workers and referents

\begin{tabular}{|c|c|c|c|c|c|c|c|}
\hline \multirow[b]{2}{*}{ Case No } & \multirow[b]{2}{*}{ Subtype } & \multicolumn{6}{|l|}{ Antibody } \\
\hline & & Vimentin & $C A M 5 \cdot 2$ & $A E 1 / A E 3$ & $E M A$ & $C E A$ & Desmin \\
\hline \multicolumn{8}{|c|}{ Asbestos cement workers } \\
\hline 1 & Epithelial & 1 & 2 & 2 & 2 & 0 & - \\
\hline 2 & Epithelial & 0 & 2 & 0 & 2 & 0 & - \\
\hline 3 & Epithelial & 2 & 2 & 2 & 2 & 0 & - \\
\hline 4 & Mixed & 1 & 2 & 2 & 1 & 0 & - \\
\hline 5 & Mixed & 2 & 2 & 2 & 2 & 0 & - \\
\hline $6+a$ & - & 0 & 2 & 2 & 2 & 2 & - \\
\hline b & Mixed & 2 & 2 & $\overrightarrow{1}$ & 2 & 0 & - \\
\hline 7 & Mixed & 2 & 2 & 0 & 1 & 0 & - \\
\hline 8 & Mixed & 1 & 2 & 1 & 1 & 0 & - \\
\hline $9+a$ & $\bar{M}$ & 2 & 0 & 0 & - & - & 2 \\
\hline b & Mixed & 2 & 2 & 2 & 2 & 0 & 0 \\
\hline 10 & Mixed & 2 & 2 & 2 & 2 & 0 & - \\
\hline 11 & Fibrous & 2 & 0 & 0 & 0 & 0 & - \\
\hline $12 \S$ & Fibrous & - & - & - & - & - & - \\
\hline 13 & Fibrous & 1 & 2 & 1 & 2 & 0 & - \\
\hline \multicolumn{8}{|c|}{ Referents } \\
\hline 14 & Mixed & 1 & 2 & 2 & 2 & 0 & - \\
\hline
\end{tabular}

$0=$ Negative; 1 = weakly positive; 2 = strongly positive.

*World Health Organisation classification of mesothelioma.

+ Case No 6; $a=$ urothelial carcinoma in 1962; $b=$ mesothelioma in 1967.

+ Case No 9; $\mathrm{a}=$ myxofibrosarcoma in $1978 ; \mathrm{b}=$ mesothelioma in 1985.

$\$$ Material for immunohistochemistry not available.

deaths) in the exposed cohort, diagnosed from the histopathological review. One pleural mesothelioma was found among the referents (a sugar refinery worker). Table 3 gives the results of the histopathological and immunohistochemical examinations. No case of peritoneal mesothelioma was found. The death rates for the remaining respiratory cancers did not differ significantly between the cohorts, but the ratio was still close to two (table 2).

Cancer morbidity for the period 1958-86 showed a similar pattern with an increased incidence for all sites ( $R R=1.3,95 \%, C I=1.0-1 \cdot 7)$ and the respiratory tract $(R R=1.6,95 \% \mathrm{CI}=0.9-3.0$; mainly due to pleural mesotheliomas) in the exposed cohort. One case of laryngeal carcinoma was found. The RR for cancer in the upper gastrointestinal tract was less than one $(R R=0.9,95 \% C I=0.5-1.8)$, but was greater than one for the lower tract $(R R=1 \cdot 7,95 \%$ $\mathrm{CI}=0 \cdot 9-3 \cdot 4)$.

DOSE RESPONSE RELATIONS

Non-malignant respiratory disease

No dose response pattern was found between time of employment and death from non-malignant respiratory disease. On the contrary, the RR was of a similar magnitude and significantly raised in each

Table $4 R R$ stratified by cumulative dose of asbestos $(f$-years $/ \mathrm{ml})$ for overall and cause specific mortality for the period 1927-86 among 1118 asbestos cement workers compared with cohort of 762 referents (minimum latency time 20 years)

\begin{tabular}{|c|c|c|c|c|c|c|c|}
\hline \multirow[b]{2}{*}{$\begin{array}{l}\text { Cumulative dose } \\
\text { Median/mean dose } \\
\text { Person-years } \\
\text { Cause of death }\end{array}$} & \multirow{2}{*}{$\begin{array}{l}\text { Referents } \\
0 / 0 \\
10910 \\
\text { No of } \\
\text { deaths }\end{array}$} & \multicolumn{6}{|c|}{ Asbestos cement workers } \\
\hline & & $\begin{array}{l}\text { All } \\
2 \cdot 8 / 13 \cdot 0 \\
17028 \\
\text { No of } \\
\text { deaths }\end{array}$ & $\begin{array}{l}<15 \text { f-years } / \mathrm{ml} \\
1.4 / 3 \cdot 1 \\
12196 \\
R R \\
(95 \% \mathrm{CI})\end{array}$ & $\begin{array}{l}15-39 \text { f-years } / \mathrm{ml} \\
24 \cdot 2 / 25 \cdot 6 \\
2934 \\
R R \\
(95 \% \mathrm{CI})\end{array}$ & $\begin{array}{l}\geqslant 40 \text { f-years } / \mathrm{ml} \\
67 \cdot 0 / 88 \cdot 2 \\
1898 \\
R R \\
(95 \% \mathrm{CI})\end{array}$ & p Value V $^{\star}$ & $\begin{array}{l}\text { Slope } \\
(95 \% \mathrm{CI})+\end{array}$ \\
\hline $\begin{array}{l}\text { Heart disease } \\
\text { Respiratory disease: }\end{array}$ & 112 & 173 & $1 \cdot 1(0 \cdot 87-1 \cdot 5)$ & $0.9(0.6-1.4)$ & $1 \cdot 2(0 \cdot 8-1 \cdot 9)$ & $0 \cdot 7$ & \\
\hline $\begin{array}{l}\text { Non-malignant } \\
\text { Malignant } \\
\text { Mesotheliomał } \\
\text { Except mesothelioma } \\
\text { Gastrointestinal cancer: } \\
\text { Upper } \\
\text { Lower } \\
\text { All tumours } \\
\text { All causes }\end{array}$ & $\begin{array}{r}13 \\
10 \\
1 \\
10 \\
22 \\
12 \\
10 \\
58 \\
279\end{array}$ & $\begin{array}{r}46 \\
38 \\
12 \\
27 \\
39 \\
18 \\
21 \\
136 \\
466\end{array}$ & $\begin{array}{l}2.8(1.4-5.3) \\
2.0(0.92-4.2) \\
1.9(0.2-21.3) \\
1.8(0.8-3.9) \\
1.0(0.6-1.8) \\
0.8(0.3-1.8) \\
1.3(0.5-2.9) \\
1.5(1.05-2.1) \\
1.2(1.01-1.4)\end{array}$ & $\begin{array}{l}2.7(1 \cdot 1-6 \cdot 3) \\
3.9(1 \cdot 7-9 \cdot 1) \\
21 \cdot 2(2 \cdot 5-178) \\
1.9(0 \cdot 7-5 \cdot 3) \\
1.4(0.6-3 \cdot 1) \\
1.6(0.6-4 \cdot 4) \\
1 \cdot 1(0 \cdot 3-3 \cdot 9) \\
2 \cdot 0(1 \cdot 3-3 \cdot 1) \\
1 \cdot 2(0.94-1 \cdot 5)\end{array}$ & $\begin{array}{l}3.3(1.3-8.3) \\
3.8(1.4-10.5) \\
22.8(2.4-212) \\
1.9(0.5-7 \cdot 1) \\
1.8(0.8-4.2) \\
1.7(0.2-3.3) \\
3.4(1.2-9.5) \\
1.9(1.1-3.2) \\
1.3(0.95-1.7)\end{array}$ & $\begin{array}{l}0.1 \\
0.01 \\
0.004 \\
0.5 \\
0.11 \\
0.9 \\
0.04 \\
0.02 \\
0.2\end{array}$ & $\begin{array}{l}1.7(0.5-2.9) \% \\
3.7(1.8-5.6) \%\end{array}$ \\
\hline
\end{tabular}

$\star$ Two tailed p value.

+Estimated multiplicative percentage increase per $\mathrm{f}-\mathrm{year} / \mathrm{ml}$

$\ddagger$ Diagnosis based on histopathological review; one of the exposed and one of the referent cases were originally coded as non-malignant and were therefore not included in the sum of all respiratory cancers (based on death certificates). 
interval ( $<$ one year, $2 \cdot 4 ; 1-9$ years, $2 \cdot 6 ; 10-24$ years, $3 \cdot 5 ; \geqslant 25$ years, $2 \cdot 5$ ). Analysis in relation to cumulative dose showed an increasing trend, mainly due to a generally increased risk when compared with the referents (table 4).

\section{Pleural mesothelioma}

A highly significant dose response relation was found between mortality from pleural mesothelioma and duration of employment with an estimated multiplicative increase of $10.4 \%(95 \% \mathrm{CI}=6 \cdot 0-14 \cdot 9)$ in the incidence for each year of employment. The same was found for cumulative dose (table 4). Three cases were lost in the analysis of cancer morbidity due to a shorter (later) period of observation, but the estimated increase with duration of employment time was similar to the one obtained for mortality; for cumulative dose (where a further case was excluded) it did not reach significance.

The nested case referent study, performed to separate the effects of latency time and dose, showed a significant time dependent dose response relation between the $R R$ and exposure $(p=0.01$, likelihood ratio statistic). As to the risk related to exposure in a certain period, a significant relation was found for cumulative exposure of 40 years or more before the diagnosis of the case, with an estimated multi- plicative risk of 1.9 for each $\mathrm{f}$-year $/ \mathrm{ml}$, and a tendency towards such a relation for cumulative exposure 3039 years before the case with a multiplicative risk estimate of $1 \cdot 1$ for each $\mathrm{f}$-year/ml (fig 1 ). No association was found between risk of pleural mesothelioma and duration of exposure when latency was accounted for in a similar way. Intensity was significant only in the 40 years or more before the diagnosis after adjustment for duration of employment and latency (increase in $\mathrm{RR}=2.7 \mathrm{per} \mathrm{f} / \mathrm{ml}, \mathrm{p}=0.03$ ).

\section{Other respiratory cancers}

After exclusion of mesotheliomas, no significant dose response relations for other respiratory cancers with employment period or cumulated dose, were found either for mortality or morbidity.

\section{All respiratory cancers}

As the number of diagnosed cases of mesothelioma might be related to the availability of tissue and necropsy rate, the dose response analysis was repeated for the sum of all respiratory cancers. This analysis showed a clearly increased risk with the number of years worked (mortality is shown in fig 2 ; morbidity, $3 \cdot 0(95 \%$ CI $1 \cdot 0-5 \cdot 1) \%$ increase in rate each year), but was less clear for mortality in relatiog

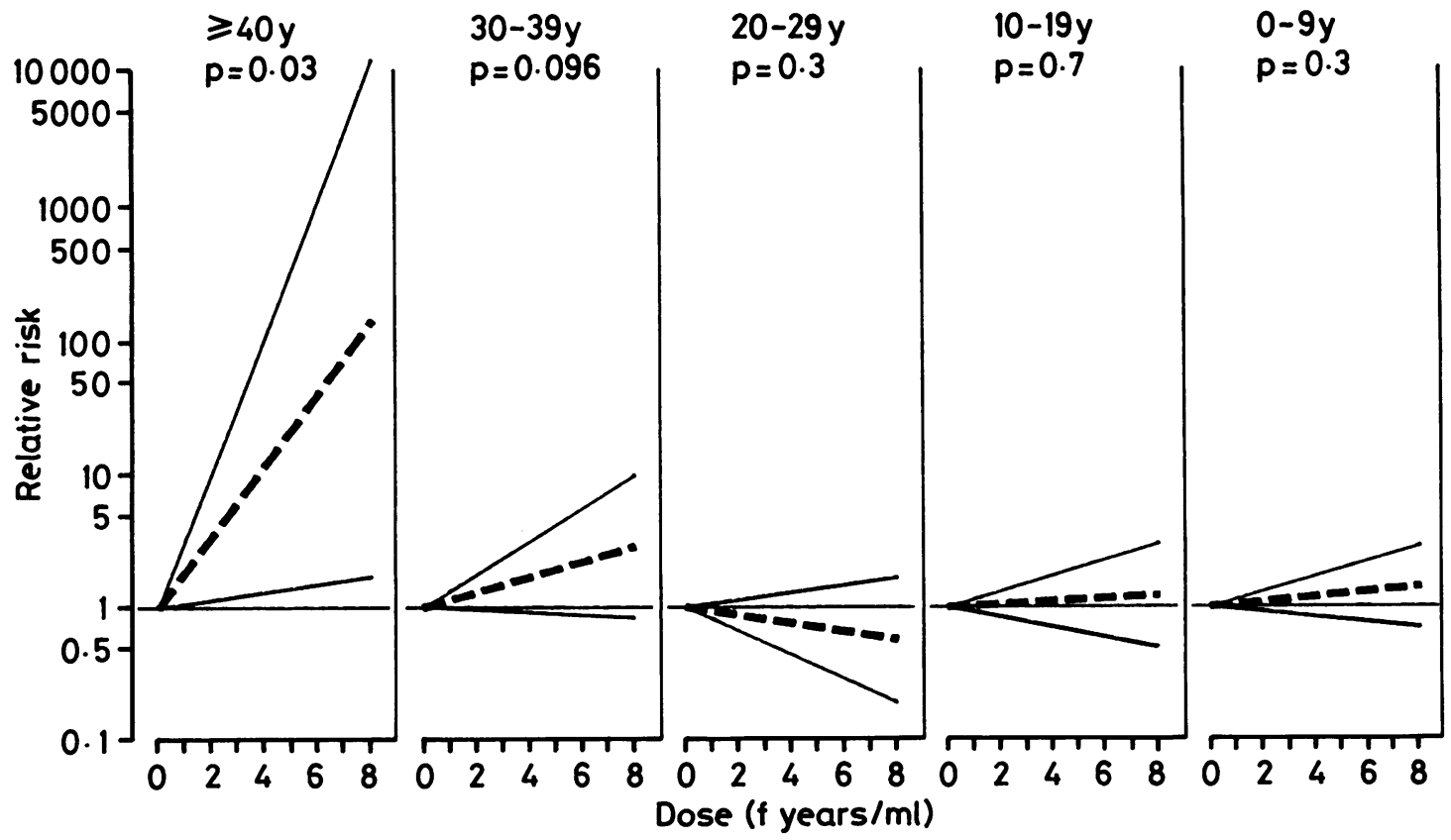

Figure 1 RRs (--) and 95\% CIs (-) for cumulative dose estimated in each 10 year period before diagnosis of mesothelioma $(n=14)$. Estimates were obtained from a conditional logistic regression analysis in which previous and subsequent exposure were adjusted for. 


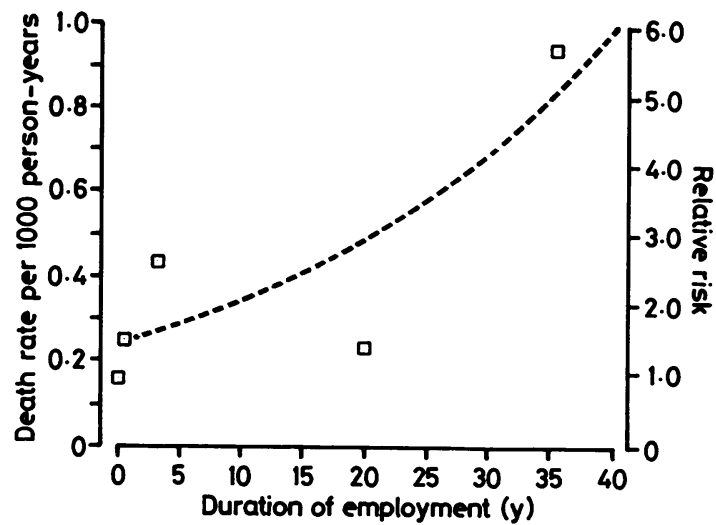

Figure 2 Death rate and corresponding $R R$ from all respiratory cancers (1927-86) v exposure time for 1454 asbestos cement workers and 762 referents (time 0) with a minimum of 20 years latency time. Squares and dashed line are derived from Poisson regression models adjusted for calendar period, age, and duration of employment and are shown for 1947-56 and age group 50-59. Slope estimate is $3.6 \%(95 \% \mathrm{CI} 1 \cdot 7-5 \cdot 5)$ a year.

to cumulative dose (table 4; nine cases without dose estimates; morbidity, 1.5 (95\% CI $0 \cdot 2-2 \cdot 8) \%$ increase each $\mathrm{f}$-year $/ \mathrm{ml}$ ).

\section{Upper gastrointestinal tract}

Cancer mortality and morbidity in the upper gastrointestinal tract (oesophagus, stomach, and duodenum) showed no dose response relation with duration of employment or cumulative dose.

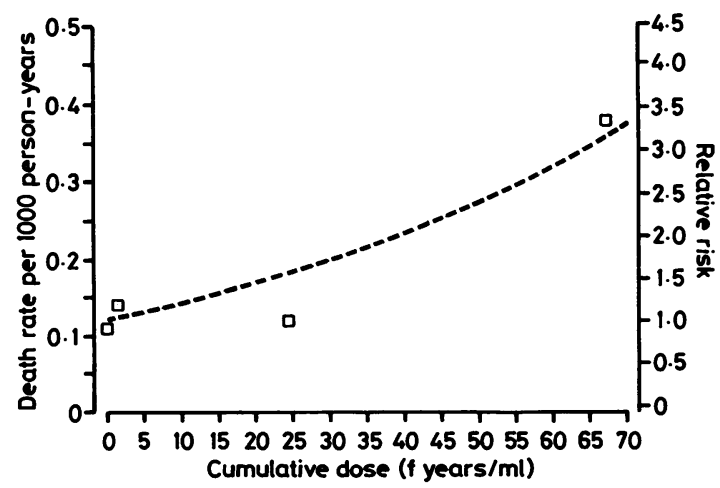

Figure 3 Death rate and corresponding $R R$ from colorectal cancer (1927-86) $v$ cumulated dose for 1118 asbestos cement workers and 762 referents (dose 0 ) with a minimum of 20 years latency time. Squares and dashed line are derived from Poisson regression models adjusted for calendar period, age, and dose, and are shown for 1947-56 and age group 50-59. Slope estimate is $1.6(95 \%$ CI 0.2-3.1)\% per f-year $/ \mathrm{ml}$.

\section{Lower gastrointestinal tract}

The risk for cancer (deaths and incidence) in the lower gastrointestinal tract (colon and rectum) showed no relation with duration of employment. A significant dose response relation was, however, found between cumulative exposure and mortality (table 4 and fig 3), and a tendency towards such a relation for morbidity with a similar estimate of slope $(1 \cdot 2(95 \% \mathrm{CI}=-0 \cdot 2-2 \cdot 6) \%$ increase each $\mathrm{f}$-year $/ \mathrm{ml}$; $p=0 \cdot 11$, two tailed test). The relative risk for mortality (table 4) was significantly greater than one in the highest ( $\geqslant 40 \mathrm{f}$-year $/ \mathrm{ml}$ ) exposure group (morbidity, $R R=2.8(95 \% \mathrm{CI}=0.98-8 \cdot 2)$, where all but one of the cases were verified by histopathological review.

Mortality (table 4) and morbidity from all malignancies increased with increasing dose (morbidity, $0.7(95 \% \mathrm{CI}=0.2-1 \cdot 3) \%$ increase each $\mathrm{f}$-year $/ \mathrm{ml})$, but not with years worked. The association disappeared when all respiratory cancers and colorectal cancers were excluded.

The overall mortality showed no relation with duration of employment or dust exposure; neither did heart disease (coronary and unspecified).

\section{Discussion \\ EXPOSURE}

The assessment of exposure in this study was difficult because of three factors-namely, incomplete work histories, the conversion from particle to fibre counts, and the lack of dust measurements for the period 1907-55.

Work histories could not be obtained for $22 \%$ of the workers, and only the first assignment was known for some others; this was not considered likely, however, to cause spurious positive dose response relations.

Conversion from particle to fibre counts was inevitable, as both methods were used in different periods and a transformation was necessary to apply the experience of past exposure to present working conditions, where levels are measured as $\mathrm{f} / \mathrm{ml}$. As no general constant for conversion existed within branches or even within a plant, ${ }^{8-10}$ each site and period of work was transformed separately. The factors used were compatible with those used in another Swedish asbestos cement factory, ${ }^{11}$ but lower than those in mining, ${ }^{9}$ textile, ${ }^{8}$ and some other asbestos cement plants. ${ }^{10}$ We did not adjust for the fact that present rules of filter preparation and fibre counting were likely to give approximately $30-50 \%$ (Cherilyn Tillman, personal communication) higher concentration than fibre counts made before 1978 .

Before 1942 the real exposure may have been greatly underestimated for some tasks, but workers engaged in these operations constitute only a small 
fraction $(5-10 \%)$ of the total cohort. Further, our approximation of exposure is supported by the fact that a similar pattern of dose response relations was seen in the group that only started employment after 1941. We estimate that the assigned dust concentrations 1942-77 are, on average, accurate within a factor of two, but may be too low for some workers (millers, mixers, sawyers, and grinders). These workers were compared, however, with those not known to have performed these tasks, and did not show a higher risk than the others (data not presented).

Our exposure estimates are similar to those found in some studies of asbestos cement plants, ${ }^{11}{ }^{12}$ but lower than in others. ${ }^{21314} \mathrm{~A}$ possible explanation of high estimates is a predominance of stationary (instead of more relevant personal) sampling in earlier periods interpreted without consideration of time weighted averages; even when comparing measurements in these other factories by related methods in the same periods and in manufacture of similar products our exposures were still lower, probably due to differences in technology. The median estimated cumulated exposure was low; this favours assessment of risks at low doses, but provides low power with regard to high exposure effects.

\section{TOTAL MORTALITY}

An increased overall mortality was found. This is in accordance with other studies ${ }^{13-16}$ but in these, the exposure was much higher. We found no dose response pattern; hence this result must be interpreted with caution. Our study is sensitive, however, due to the choice of industrial workers as a reference cohort and a long observation period. The increase was also confirmed in a comparison with the population in the region (M Albin et al, Proceedings of the VIIth International Pneumoconioses Conference. Pittsburgh, August 1988).

\section{NON-MALIGNANT RESPIRATORY DISEASE}

The mortality from all non-malignant respiratory disease was, surprisingly, increased in all exposure categories when compared with the referents. This is not in agreement with earlier data on dose response for mortality from, or for clinical findings indicating asbestosis. ${ }^{9}$ Cumulative doses from five to $30 \mathrm{f}$-years/ $\mathrm{ml}^{17}$ and $20 \mathrm{f}$-years $/ \mathrm{ml}^{18}$ respectively, however, have been found to induce an increased score of histologically verified pulmonary fibrosis. The main risk for the group of non-malignant respiratory diseases was (in contrast to the malignancies) confined to the early observation period, where the imprecision in the individual dose assessment was greatest. This might have contributed to an arbitrarily even risk over the exposure strata, and thereby the increase in the lowest exposure category. Considering the dose response for histopathological fibrosis the raised risk from approximately $15 \mathrm{f}$-years $/ \mathrm{ml}$ could tentatively be explained by fatalities from intercurrent infectious diseases in compromised hosts. This would also provide a possible explanation for the pattern of decreasing risk with calendar time.

\section{RESPIRATORY CANCERS}

An increased mortality and morbidity from respiratory cancer were found. The increases with duration of employment were higher than those usually reported for the asbestos cement industry, ${ }^{211} 12$ but were lower than in one study..$^{13}$ The increase in risk with every $\mathrm{f}$ year $/ \mathrm{ml}$ was higher than the estimate of lifetime risk for respiratory (mesothelioma and lung) cancer from chrysotile exposure only, given by Doll and Peto. ${ }^{19}$ If mesotheliomas were excluded there was a numerical increase (but with a wide confidence interval; 10 reference cases). This agrees with a comparison with the general population where a statistically verified risk of the same magnitude was found (M Albin et al).

\section{MESOTHELIOMAS}

The diagnosis of mesothelioma is controversial. In our opinion the diagnosis must always be based on light microscopy with a histopathological pattern acceptable as an epithelial, mixed, or fibrous meso thelioma. Immunohistochemical examination has been used by several authors to distinguish mesothelioma from metastatic adenocarcinoma, as meso? theliomas as well as adenocarcinomas are immunoreactive with cytokeratin; CEA is positive with most adenocarcinomas, but only occasionally with mesotheliomas. ${ }^{2021}$ All cases presented here were negative for CEA. A high proportion of the mesotheliomas were mixed (eight out of 14) compared with $30 \%$ in consecutive mesotheliomas at Lund University Hospital.

Dose response relations for mesothelioma were established both with duration of exposure and cumulative dose, when compared with the referent cohort. As latency time has been shown to have a strong effect on the risk for pleural mesothelioma, ${ }^{19}$ these results could possibly have been an effect of latency alone. A dose response relation was also confirmed, however, after taking the effect of latency time into account in the internal case referent study. In this study every $\mathrm{f}$-year $/ \mathrm{ml}$ of exposure 40 years or more before the diagnosis, had a major impact on the relative risk. The mesothelioma rates in the highest exposure categories correspond to lifetime risks of as much as $5-10 \%$. These rates are compatible with those found in cohorts of insulators, ${ }^{16}$ asbestos factory workers, ${ }^{22}$ and two other cohorts of asbestos cement workers. ${ }^{13}{ }^{14}$ They are, however, considerably higher than those reported for other asbestos cement plants. ${ }^{211} 12$

The high rate of necropsies in the cohort $(64 \%)$ 
enhanced the possibility of detecting and verifying cases of mesothelioma. This might explain part of our high mesothelioma rate compared with cohorts with a low rate of necropsies (and preserved tissue for review), or where no histopathological review has been performed; although in the study by Newhouse and coworkers necropsy reports and histological material were reviewed in about half of the deaths in the follow up. ${ }^{22}$

Mesothelioma is mainly associated with amphiboles. Manufacture of asbestos cement products is usually based on chrysotile supplemented with amosite and crocidolite in amounts that vary between plants and over time, often without full retrospective information. Evaluation of risk in relation to fibre type from exposure histories only is therefore difficult. A definite difference in amphibole use was found only between one of the asbestos cement plants with a low mesothelioma risk $^{12}$ and the plant we studied. Exposure to commercial amphiboles (amosite and crocidolite) may have occurred in all our cases, although these constitute only a small fraction of the total exposure to asbestos. Concomitant to chrysotile, there was exposure to tremolite which has been associated with mesothelioma in other studies. ${ }^{23}$ Lung tissue from seven of the mesotheliomas was examined with transmission electron microscopy for mineral fibre content, and had much higher crocidolite and also higher total asbestos and tremolite counts when compared with matched nonexposure cases from the cohort (M Albin et al).

We found no peritoneal mesothelioma. It is well known that the relation between pleural and peritoneal mesotheliomas varies widely between study groups, even when tissue review has been performed. ${ }^{24}$ It has been argued that peritoneal mesotheliomas are linked mainly with intense and prolonged exposure. ${ }^{24}$ Thus in a study of the mineral fibre content in lung tissue the asbestos counts among cases of peritoneal mesothelioma were twice as high as among cases of pleural mesothelioma. ${ }^{25}$ The predominance of pleural mesotheliomas in our study could, therefore, be due to the comparatively low cumulative exposure.

\section{GASTROINTESTINAL CANCER}

No overall excess risk from cancer in the upper or lower gastrointestinal tract was found in the exposed cohort. Nevertheless, dose response relations were found between colorectal cancer and cumulative dose, with an estimated increase each $\mathrm{f}$-year $/ \mathrm{ml}$ of the same magnitude as that for respiratory cancer. To exclude misdiagnosed peritoneal mesotheliomas, the histopathological material was reviewed, but no case of certified or probable mesothelioma was found.

High social status is known to be positively related to cancer in the colon and rectum, ${ }^{26}$ but the two cohorts were selected to be comparable from this aspect. Diet (high fat intake and low fibre content), low physical activity, ${ }^{27}$ and exposure to stainless steel dust ${ }^{28}$ may be risk factors but we have no reason to assume that they differed between the cohorts.

Workers exposed to cement have been reported to have an increased risk for stomach cancer. ${ }^{29}$ In the same study an excess of rectal cancer was found in one group of workers, but there was no suggestion of a dose response relation. Moreover, in a case referent study of colorectal cancer, there was an overrepresentation of cement workers ( $\mathrm{K}$ Jakobsson $e t$ al, unpublished data). Thus the present overrisk of colorectal cancer in highly exposed workers might be due to cement exposure. There are, however, several other studies of asbestos cement workers, ${ }^{211-14}$ in which there was no increase in colorectal cancer. There are indications of an increased risk of colorectal cancer from asbestos. Among workers in chrysotile mines who have no concomitant cement exposure, dose response relations were found between cumulated dust exposure and cancer of the colon and rectum, albeit with a flatter slope. ${ }^{30}$ The differences in the slopes may tentatively be explained by a combination of asbestos type (some amphiboles), fibre treatment (disintegration of fibre bundles by milling, possibly causing a higher proportion of submicroscopic fibres), and the absence in our study, due to relatively low exposure, of lung cancer as a major competitive cause of death.

This project was supported by grants from the Swedish Work Environment Fund, and from Ellen, Walter, and Lennart Hesselman's Foundation for Scientific Research. We acknowledge cooperation with the Southern Swedish Regional Tumour Registry, Lund. We also thank Ms Viveka Englander, Ms Gertrud Lennartsson, Mr Nils-Göran Lundström, laboratory technician Ms Kristina Andersson, the late Mr Gunnar Nilsson, and Professor Axel Ahlmark for valuable help.

Requests for reprints to: Maria Albin, Department of Occupational and Environmental Medicine, University Hospital, S-221 85 Lund, Sweden.

1 McDonald AD, Fry JS, Woolley AJ, McDonald JC. Dust exposure and mortality in an American chrysotile textile plant. Br J Ind Med 1983;40:361-7.

2 Hughes JM, Weill H, Hammad YY. Mortality of workers employed in two asbestos cement manufacturing plants. $\mathrm{Br} J$ Ind Med 1987;44:161-74.

3 Todd JC. Sharp competition for shagging markets in 1981. Engineering and Mining Journal March 1982:125-7.

4 World Health Organisation. The World Health Organisation histological typing of lung tumors. 2nd ed. Am J Clin Pathol 1982;77:123-36.

5 Frome EL, Checkoway $\mathrm{H}$. Use of Poisson regression models in 
estimating incidence rates and ratios. Am $J$ Epidemiol 1985; 121:309-23.

6 Breslow NE, Lubin JH, Marek P, Langholz B. Multiplicative models and cohort analysis. Journal of the American Statistical Association 1983;78:1-12.

7 Breslow NE, Day NE. Statistical methods in cancer research. Vol 1. The analysis of case-control studies. Lyon: International Agency for Research on Cancer, 1980. (IARC sci publ No 32 .)

8 Lynch JR, Ayer HE, Johnson DL. The interrelationships of selected asbestos exposure indices. Am Ind Hyg Assoc J 1970;31:598-604.

9 Gibbs GW, Lachance M. Dust-fiber relationships in the Quebec chrysotile industry. Arch Environ Health 1974;28:69-71.

10 Hammad YY, Diem J, Weill $H$. Evaluation of dust exposure in asbestos cement manufacturing operations. Am Ind Hyg Assoc $J 1979 ; 40: 490-5$.

11 Ohlson C-G, Hogstedt C. Lung cancer among asbestos cement workers. A Swedish cohort study and a review. $\mathrm{Br} J$ Ind Med 1985;42:397-402.

12 Gardner MJ, Winter PD, Pannett B, Powell CA. Follow up study of workers manufacturing chrysotile asbestos cement products. Br J Ind Med 1986;43:726-32.

13 Finkelstein MM. Mortality among employees of an Ontario asbestos-cement factory. Am Rev Respir Dis 1984;129:754-61

14 Raffin E, Lynge E, Juel K, Korsgaard B. Incidence of cancer and mortality among employees in the asbestos cement industry in Denmark. Br J Ind Med 1989;46:90-6.

15 Doll R. Mortality from lung cancer in asbestos workers. Br J Ind Med 1955;12:81-6.

16 Selikoff IJ, Hammond EC, Seidman H. Mortality experience of insulation workers in the United States and Canada, 19431976. Ann NY Acad Sci 1979;330:91-116.

17 Green FHY, Harley R, Vallyathan V, Dement J, Pooley F, Althouse R. Pulmonary fibrosis and asbestos exposure in chrysotile asbestos textile workers: preliminary results. In: Wagner JC, ed. The biological effects of chrysotile. Philadelphia: Lippincott, 1986:59-68.

18 Johansson LG, Albin MP, Jakobsson KM, Welinder HEC, Ranstam PJ, Attewell RG. Ferruginous bodies and pulmonary fibrosis in dead low to moderately exposed asbestos cement workers: histological examination. $\mathrm{Br} J$ Ind Med 1987;44:
$550-8$.

19 Doll R, Peto J. Asbestos. Effects on health of exposure to asbestos. A report to the Health and Safety Commission. London: HMSO, 1985.

20 Corson JM, Pinkus GS. Mesothelioma: profile of keratin proteins and carcinoembryonic antigen. An immuno-peroxidase study of 20 cases and comparison with pulmonary adenocarcinoma. Am J Pathol 1982;108:80-7.

21 Otis CN, Carter D, Cole S, Battifora H. Immunohistochemical evaluation of pleural mesothelioma and pulmonary adenocarcinoma. A bi-institutional study of 47 cases. Am J Surg Pathol 1987;11:445-56.

22 Newhouse ML, Berry G, Wagner JC. Mortality of factory $\mathrm{C}$ workers in east London 1933-80. Br J Ind Med 1986;42:4-11.

23 McDonald JC, McDonald AD, Armstrong B, Sebastien P. Cohort study of mortality of vermiculite miners exposed to tremolite. Br J Ind Med 1986;43:436-44.

24 Browne K, Smither WJ. Asbestos-related mesothelioma: factors discriminating between pleural and peritoneal sites. $\mathrm{Br} J$ Ind Med 1983;40:145-52.

25 Wagner JC, Newhouse ML, Corrin B, Rossiter CE, Griffiths DM. Correlation between fibre content of the lung and disease in east London asbestos factory workers. $\mathrm{Br} J$ Ind Med 1988; 45:305-8.

26 Vảgerö D, Persson G. Occurrence of cancer in socioeconomic groups in Sweden. Scand J Soc Med 1986;14:151-60.

27 Gerhardsson M, Norell SE, Kiviranta H, Pedersen NL, Ahlbom A. Sedentary jobs and colon cancer. Am J Epidemiol 1986; 123:775-80.

28 Svensson BG, Englander V, A kesson B, Attewell R, Skerfving S, Ericsson $\AA$, Möller T. Deaths and tumours among workers grinding stainless steel. Am J Ind Med 1989;15:51-9.

29 McDowall ME. A mortality study of cement workers. $\mathrm{Br} \mathrm{J}$ Ind Med 1984;41:179-82.

30 McDonald JC, Lidell FDK, Gibbs GW, Eyssen GE, McDonald AD. Dust exposure and mortality in chrysotile mining, 191975. Br J Ind Med 1980;37:11-24.

Accepted 5 February 1990 